CARL B. SELL

Lock Haven University

iD https://orcid.org/0000-0002-3443-2691

\title{
"My Honor is My Life": Sturm Brightblade of the Dragonlance Saga and Middle English Arthurian Knighthood
}

\begin{abstract}
Arthuriana has a long history of adaptation and appropriation in medieval and contemporary works, and the tradition of such textual borrowing and reworking continues in contemporary "genre" novels, particularly those that invoke associations with knights, honor, and codes of chivalry. One such example are the novels and short stories of the Dragonlance setting. Sturm Brightblade is positioned as a knight who adheres to a code of honor and is given Arthurian character traits, narrative arcs, and a backstory by the various authors that have fleshed out his history. The texts in the Dragonlance setting knowingly use appropriated elements from Middle English Arthurian works and assign them to Sturm Brightblade to give him proper positioning as a knight that would fit in with Arthur's legendary Round Table.
\end{abstract}

KeYwords: Arthurian, Dragonlance, appropriation, fantasy, knighthood

Fantasy novels that are not written by J. R. R. Tolkien, especially those published under the Dungeons \& Dragons moniker, are often derided as "pulp," implying that they are "mere beach reading." To paraphrase a scholar I once spoke with: they are a good read for a long afternoon, but are not seen as analytically stimulating or intellectually composed. This scholar echoes a sentiment expressed by Umberto Eco, who states that "we are looking for 'reliable Middle Ages,' not for romance and fantasy, though frequently this wish is misunderstood and, moved by a vague impulse, we indulge in a sort of escapism à la Tolkien" (Eco, 1986: 65). Eco's harsh reaction to popular representations of the medieval in fantasy has helped establish their place on the outskirts of any critical inquiry. Indeed, there is next to no critical work on such novels, and what can be found is often critical in terms of why they should be devalued rather than valued. However, these works are no different from the fantasy works which scholars consider "literary." The same process of invoking mythic tem- 
plates occurs in these popular fictions, and the mythic template of King Arthur proves to be a fruitful source for such invocations. I see the study of Arthurian appropriations in popular fictions as a way to bridge a perceived gap between Arthurian scholars and the "casual" audiences of new Arthurian adaptations and appropriations. Raymond H. Thompson asserts that

modern retellings, whether they be translations from foreign languages, or modernizations of archaic forms of their own languages [...] encourage an interest in the legend that can lead readers back to study original texts or to read other versions, modern as well as ancient. They help create the audience without which a legend fades from sight.

(Thompson, 1985: 12)

In short, new Arthurian works - whether adaptations or appropriations serve as entry points for many new readers to encounter other Arthurian texts, including the medieval sources upon which these "modern retellings" draw. My addendum to Thompson's words is that, for those readers who have already read or familiarized themselves with other Arthurian works, these entry-points, allusions, and sign-posts serve as markers of influence, of source-borrowing, and the reworking of previous versions of these Arthurian characters and themes adds value to these popular fictions.

The authors of such works use the popularity of their intended form and their source material to their ultimate benefit: they are aware that their genres lean on literary giants, and they appropriate both eagerly and effectively, entering into the larger discussion of the Arthurian adaptive tradition. However, the signals of association work differently in these popular texts, as they often rework Arthurian material so that their own characters and settings have a strong, popular groundwork from which to diverge and build. Yet, it must be noted that the Matter of Britain still exists in these works, and it is Arthur who is the strong, mythic base from which such fantasies often spring. As a result, they must be studied alongside more established appropriative works, as their literary merit exists as long as Arthur proves useful and the Once and Future King's usefulness has long been proven.

A key signature of the appropriation - rather than "adaptation," which these works most assuredly are not - of Arthurian material in otherwise non-Arthurian novels is that many Arthurian characters are often hybridized into a single character in the course of the appropriation. In Adaptation and Appropriation, Julie Sanders defines an appropriation as a text that "frequently effects a more decisive journey away from the informing text into a wholly new cultural product and domain, often through the actions of interpolation and critique as much as through the movement from one genre to others" (Sanders, 2016: 35). I argue that the critique presented by appropriations is not always of the contemporary culture, as some critics might suggest; instead, it is rather a commentary on 
what Arthurian elements should be included, shifted, reinterpreted, or recontextualized for each genre and medium. Sanders also acknowledges that "appropriation may or may not involve a generic shift and it may certainly still require the kinds of 'readings alongside' or comparative approaches that juxtapose (at least) one text against another" (Sanders, 2016: 35). Truthfully, Arthurian appropriations are very difficult to read in a critical manner without the knowledge of the texts they draw from and rework. What separates appropriation more fully from adaptation, I argue, is the remolding of the source material in such a way that it radically reworks and revises Arthurian content to fit a new - in this case, fantasy - setting. Linda Hutcheon argues that, rather than adapting for the sake of sharing a story in a new context, "the name of the new adaptation game" is "world building," using adapted material to create one's own setting for new and varied adventures (Hutcheon, 2013: xxiv). Sanders, however, would say that this is different than adaptation, and I personally agree. Thus, taking material to build one's own world is not adaptation, but, rather, appropriation. However, this act still necessitates the side-by-side readings that both Sanders and Hutcheon call for, but more fully embraces Sanders's later ideas on the use of a "mythic template" that is constantly reworked and reused to create new works that are linked to previous traditions, yet are also a part of a new textual lineage (Sanders, 2016: 81) - which is exactly where the Dragonlance novels situate themselves. It is then the use of Arthurian elements in a wholly new setting and amalgam which makes these novels wholly new products that remain tied to their sources.

I argue that it was a conscious decision for the authors in question to combine primarily Middle English Arthurian texts, themes, and characters into one or possibly two characters in the appropriation to enact a revised Arthurian plot. The dual act of combination and reworking prevents the Arthurian material from entirely overwhelming the rest of the novel while also presenting a representative figure (or figures) that a reader can and should associate with Arthuriana. Often, these characters are knights, kings, or heroic warriors, and serve a purpose that in some way mirrors their status as an Arthurian appropriation, most frequently in a fight for an ideal, living by a code of honor, a certain quest or series of adventures, a meaningful death, leaving a lasting legacy, or all of the aforementioned functions. Sturm Brightblade - a hero of the Dragonlance setting for both the Dungeons \& Dragons roleplaying game and its companion novels - enacts all of these Arthurian functions and, in so doing, reveals himself as an amalgam of not just one or two Arthurian figures, but four: Perceval, Gawain, Lancelot, and Arthur himself.

The Dragonlance setting was originally created by Margaret Weis and Tracy Hickman in the early 1980s as a new setting for the ongoing, TSR-based Dungeons \& Dragons roleplaying game. Weis and Hickman, along with other important players like Michael Williams, Paul B. Thompson, and Tanya C. Cook 
(née Carter), also began to expand upon the campaign setting via the long-lasting novel line begun by TSR and taken over by Wizards of the Coast when they purchased TSR in 1997. The novels themselves have garnered little scholarly attention, likely due to their "pulp" status, and the only real critical study of the setting and its novels is Benjamin J. Robertson's study "From Fantasy to Franchise: Dragonlance and the Privatization of Genre," a genre-based approach that, rather unfairly, examines the Dragonlance novels as a nearly impossible - or at least improbable - undertaking for critics. Robertson is concerned with viewing certain texts "as representative of a larger abstraction" (Robertson, 2017: 129) rather than taking aim at a single line of critical inquiry. This is not to say that Robertson is incorrect in his assessment of the enormity of the task for critics looking at Dragonlance - though his own study could profit from some degree of close reading, as character names are incorrect and others are forgotten about altogether. However, a way of proceeding that establishes a clearer framework for tracing themes and narratives in the Dragonlance novels is to find the tropic appropriations which are inherent to every novel in the fantasy genre. To apply Julie Sanders, perhaps, is a better option: in an attempt to find the mythic template used by various authors in specific Dragonlance novels, one must simply know where to look and what to look for.

Robertson does ask an important question, however. The Dragonlance series of novels is made up of well over three hundred individual books; Robertson, rightly so, queries, "How do you even trace a single character's 'arc' across inconsistent texts written by multiple authors over many decades, much less the evolution of an entire story world? After all, they can't all be necessary texts - or even worthwhile ones" (Robertson, 2017: 129). Robertson may overlook a fairly obvious, but no less ingenious answer: it depends on what character one attempts to trace, or even what author - or authors, in the case of Weis and Hickman - created that character. Weis, Hickman, Williams, and other vital authors and editors released annotated versions of the first two "core" (written by Weis and Hickman) trilogies, Dragonlance Chronicles and Dragonlance Legends in 2002 and 2003, respectively. The Annotated Chronicles in particular provides many answers that Robertson raises in his article as well as common questions and concerns raised by fans, editors, other authors, and even the company. Even though some authors are not represented in these annotations - or are only given annotations for the included poetry and songs, as was Michael Williams - these annotations give many references to other Dragonlance novels. One of the keys to answering the question of "which novels and why" may be answered by the annotations, as novels that are not considered "core" are referenced, creating a kind of canonical lineage of both thematic content and character development.

My exploration of Sturm Brightblade as an Arthurian amalgam begins with an investigation into annotations. My own argument that Weis, Hickman, Wil- 
liams, and Thompson and Cook have appropriated Arthurian content into their conceptualizations of Sturm Brightblade has evolved from various levels of communication with authors and editors involved in the Dragonlance series as well as my own observations of Arthurian mythic appropriation. While Sturm first appeared in print in the novels of Weis and Hickman, a study of Sturm's Arthurian representation must begin with explorations into his early years, which were published after his death in the main Dragonlance continuity. It was established early on that Sturm was raised far away from the courts of the Knights of Solamnia due to their fall from favor in the eyes of the commoners they swore to protect. It is with the (unconfirmed) death of Sturm's father, Angriff, during the siege of Castle Brightblade by his own subjects that Sturm is sent far from the nation of Solamnia for his own protection, so that he may one day live to reclaim his birthright and become a knight. Sturm is brought up in Solace, a town amongst the forests and trees, where knighthood is virtually unknown - however, Sturm's mother instructs him in proper Solamnic ways and prepares him to one day become the knight he was born to be. Sturm's journey from Solamnia to Solace is chronicled in the short story "The Exiles" by Paul B. Thompson and Tonya R. Carter. Lady Ilys Brightblade takes her son into hiding and Sturm's firm belief in the oath of the Solamnic Knights, "est sularus oth mithas" [my honor is my life], is exhibited for the first time. This knightly oath is modeled on the Arthurian Pentecostal Oath, the Arthurian code of chivalry in Sir Thomas Malory, where Arthur:

charged them [his knights] never to do outerage nothir mourthir, and allwayes fle treson, and to gyff mercy unto hym that askith mercy, upon payne of forfeiture of theire worship and lordship of Kyne Arthure for evir More; and always to do ladyes, damsels, and jantilwomen and wydowes soccour, strengthe hem in hir ryghtes, and never to enforce them upon payne of dethe. Also that no man take no batayles in a wrongefull quarrel for no love ne for no worldis goodis.

(Malory, 2017: 97)

While the Solamnics live by a much-abbreviated version, the word "honor" to them encompasses all of the above, and Sturm in particular takes the parts about defending women to heart, as he defends his mother and her maid in "The Exiles" and later assists Goldmoon in her quest and protects Lady Alhana Starbreeze in the Chronicles. To Sturm, knighthood and honor denote protecting others when they need it most and, for him, the ends most certainly justify the means. When Sturm decides that he must defend his mother from bandits who serve Takhisis, the goddess of darkness, he reflects on his father "standing on the battlements of Castle Brightblade with only a few loyal retainers while a mob of madmen howled around them. Lord Brightblade would meet this foe face to face, head to head, to conquer or to perish. It was the knightly way. It 
was the Brightblade way" (Thompson and Carter, 1987: 198). Aside from foreshadowing his own death in Dragons of Winter Night, Sturm realizes at eleven years old that living by the knightly honor code often involves dying for a cause, dying in pursuit of an ideal. The Solamnic ideal of honor and protection of those who cannot protect themselves is similar to the code that T. H. White names "Might for Right" in The Once and Future King, what Malory himself refers to as Arthur's desire "unto his lords and the comyns for to be a true kyng, to stand with true justice fro thens forth the dayes of this lyf" (Malory, 2017: 111). The Solamnic oath, as well as their codified Measure, which shall be discussed later, has a firm basis in the Arthurian ideal not just for himself as a king, but for his knights of the Round Table as well. While all knights are alleged to be bound by a code of honor, the Solamnic Knights, and Sturm in particular, live and die for honor, and do their utmost to uphold the Solamnic Order.

Laura K. Bedwell writes that Malory, in his portrayal of Arthur as a just king, "was following the views of the people of his day, when King Arthur was already known for his justice" (Bedwell, 2011: 3), as well as for his desire to protect the weak via force of arms. Bedwell, however, argues against the perception that Arthur "is perfectly just" (Bedwell, 2011: 4) and instead sees a flawed king who not only fails to keep his knights in line with their oaths to the Round Table and to the people, but also as a man who fails to live up to his own ideal, pointing out many indicators of his shortcomings. It is worth noting that Bedwell writes that Sir Torre, "though he was brought up as a peasant, is the only one of the three who competently navigates the difficulties of knighthood" when he, Gawain, and Pellinore, undertake a joint quest (Bedwell, 2011: 5). Torre, like Perceval, is reared away from court and not subject to the intrigues, politics, and learned behavior of nobles, and is thus able to devote himself solely to the ways in which an ideal knight should behave - he knows no different, as he rose from humble beginnings. Thus is Sturm Brightblade positioned in the Dragonlance novels. Though he is raised on stories of knightly deeds and instructed as a knight (Thompson and Carter, 1987: 185) - unlike both Torre and Perceval and more like Arthur himself - he, like them, is not subjected to courtly intrigue and politics, and is, as a result, able to more readily navigate the actual portrayal of knighthood and can begin to live up to the (Arthurian) ideal of knighthood - at least as much as any mortal man is able to live up to perfection. Sturm also knowingly bends the Measure, the written strictures by which the Knights of Solamnia live, when it benefits the saving of innocent lives in "The Exiles," as he uses a magic string to defeat the bandits holding his mother and her maid captive. Knights, according to the Measure, should have nothing to do with magic, and when Sturm lies and says that "I don't know anything about magic. It's not a fitting subject for knights," he quickly follows it up with a prayer that "Paladine [the god of light] would forgive him for bending the Measure," as Sturm may not have known what would happen, but he surely knew that he was dealing 
with magic (Thompson and Carter, 1987: 207). Sturm begins his life in exile having already knowingly "bent" the Measure for good reasons, and he will continue to do so in his adult life as well, as Sturm's belief in ideal knighthood will eventually cause a reformation amongst the knights to embody "the Brightblade way," though this only comes after his death, just as a renewed sense of the Arthurian ideal only came after Arthur's loss. Bedwell notes that Arthur's "Oath is too inflexible to meet the demands of the ever-changing human situations of Arthur's realm," and continues by saying that "Instead of providing a firm foundation for justice, Arthur's Oath itself has weaknesses," the majority of which stem from the failure to fully carry out the Oath and its punishments (Bedwell, 2011: 7). Much like the Solamnic Oath and Measure, the Arthurian Oath has no room for interpretation and is met with letter-by-letter recitation and adherence; Sturm, however, sees the need to "bend" the strictures so that he can better serve the people he swore to protect. Sturm's life proves that a knight can live by the spirit of these codes if not by their exact, unbending wording, and his death proves that these changes must be made so that the knights can unite under a single leader once more - if only the same could be said of Arthur's Round Table.

Michael Williams's novel The Oath and the Measure takes a lengthier look at Sturm's adherence to the Solamnic ideal, and further cements his association with Arthurian knights by the appropriation of the narrative structure and themes of Sir Gawain and the Green Knight. Though casting Sturm as a Gawain stand-in for such a narrative is fairly obvious, Sturm's status as an Arthurian amalgam remains as attention is drawn to his upbringing away from Solamnia, since Perceval and Arthur were raised away from court for their own protection. Giving Sturm such recognizable and knightly origins and storylines is, of course, the type of reformatting of a legend that Julie Sanders has in mind, though Williams and the other Dragonlance authors who write of Sturm Brightblade most likely do not knowingly invoke critical theory; instead, they position Sturm in familiar terms for a knight of his caliber and near-mythic stature so as to be recognizable for readers of knightly fantasy and those versed in Arthurian content. The "reworking" of the Arthurian source material to fit with Sturm's own personality and with the Dragonlance setting at large is exactly the kind of adoption of a mythic template and outlines with alterations that Sanders writes of, and the structure of the myth, while being reassessed and adapted, remains an underlying guideline. Williams is the one to draw the clearest and most obvious attention to his appropriated sources and narrative themes. James Lowder, Williams's former copyeditor at TSR, writes that "Michael seemed to drop a lot of references to the Matter [of Britain], Chaucer, and so on into his books," particularly those about the Solamnic knights and Sturm Brightblade (Lowder, 2019). Indeed, an early appraisal of the young Brightblade reads like an abbreviated version of Perceval's or Arthur's upbringing: 
Smuggled from Castle Brightblade one winter's night in his eleventh year, [Sturm] remembered his father in images and episodes, as a series of events rather than a living person [...] Sturm, though, had a fabled father from scattered memories, from his mother's stories, and no doubt from sheer imagining. Angriff grew kinder and more courageous the longer the boy dreamed, and dreams became his refuge in Abanasinia, far away from the Solamnic courts, among indifferent southerners in a nondescript hamlet called Solace. There his mother, the Lady Ilys, raised him with more tutors than friends, schooling him in courtesy and lore and his heritage [...] And ruining him, Lord Stephen thought with a smile, for anything except Solamnic Knighthood.

(Williams, 2003: 4)

After the disappearance of his father at the siege of Castle Brightblade, Sturm is secluded and raised far from his birthright in much the same way as Perceval, but rather than left to run wild, Sturm is well-aware of his knightly heritage, and is schooled to be the perfect knight. In this way, he is rather more like Malory's Arthur, who is also raised away from court for his own protection, and though his identity as Uther's son is hidden, he is still trained to be a knight and given an education. Truly, Sturm can be nothing but a knight, and has become useless to any farmer or woodsman in Solace, just as the young Arthur would have been useless as a stableboy - both were meant for greater things. The Arthurian associations are made explicit to position Sturm as a hero to readers, and as someone linked to heroic beginnings in chivalric literature: the tropes Williams uses are clear signals to his audience, particularly as his main contributions to the Dragonlance novel line were books about the Solamnic knighthood - and indeed about Sturm and his family. Williams knowingly ties his knowledge of chivalric literary forms and sources with his offerings for the Dragonlance world, providing a vehicle for Arthuriana to exist in a fantasy setting, albeit underneath the surface of a narrative seemingly about other characters and another storyline.

Much like when Uther dies and Arthur is revealed - or, indeed, after Perceval's mother loses her hold over him and he escapes to the courtly realm - it is only when Sturm's mother dies that the young man is brought back into the fold of the Solamnic Knighthood, at least for a brief time. After Sturm sat vigil for his mother:

Lords Gunthar and Boniface, who had been Angriff Brightblade's closest friends, arranged to have Sturm brought back to Thelgaard Keep, where he could be further trained in the ways of the Order [...] He was smart, that was certain, and the years of genteel poverty had toughened him in ways that the northern boys secretly envied: He was knowledgeable in the woods and rode horseback like a seasoned Knight. But his southern ways and old Solamnic charm seemed like relics of the last generation to the urbane younger men, squires and Knights from prominent families. They called him "Grandpa 
Sturm" and laughed at his accent, his storehouse of remembered poetry, his attempts to grow a mustache.

(Williams, 2003: 4)

Sturm very obviously does not fit in to court life and perhaps would have been more at home in the knighthood of his father rather than with the new breed of knights whose only proof for knighthood was their birth. Sturm had already dealt with trials: the loss of his parents, separation from his homeland, and his inability to become a squire due to his time away from the knights. As a result, Sturm lived the Solamnic Oath while others merely paid it lip-service. Rather than see Sturm as a logical candidate for knighthood - or even to serve as a squire - because of his sense of knightly honor and duty, the knights see him as overly sheltered and idealistic, unknowing of how the world, let alone the court, works. In this manner, Sturm is indeed like the titular character of Sir Perceval of Galles, whose mother swept him away from Arthur's court after the death of the first Sir Perceval. The Lady Acheflour decides that:

Schall he [Perceval the Son] nowther take tent

To justes ne to tournament,

Bot in the wilde wodde went,

With bestes to playe.

[Shall he [Perceval the Son] neither take tent

To jousts nor to tournament,

But in the wild wood,

With beasts to play [with].]

11.173-76 (Braswell, 1995)

Acheflour's desire to protect her son from his father's fate meant that, though Perceval excelled in his new home in the woods, he was ill-prepared for the world of his father, the world of knighthood. When the young Perceval is thrust into courtly affairs, he is seen as a rustic, and even the lessons he learns from Gawain are not quite enough to make him the knight he so desperately wants to be. Sturm's mother, for all her good intentions, prepared Sturm for an idyllic knighthood that could never live up to his expectations, especially since the Solamnics turned away from ideal knighthood and took to courtly politics long before Sturm's arrival. While Lady Ilys has done much better than Lady Acheflour in preparing her son, she neglects to teach Sturm how to move in the world of noble intrigue and courtly affairs. Sturm is clearly set up for failure, and it is important to note that Perceval was as well: both men do not succeed at courtly life or at knighthood until their stories are nearly over, crafting a narrative structure of learning lessons and striving for excellence. A kind of lesson is imparted

\footnotetext{
${ }^{1}$ My translation.
} 
via both characters and the readers are meant to take heed of their learning curves and experiences.

Like Perceval, Sturm is not made a knight until much later, nearly at the end of his adventures. Because Williams's novel was published after Sturm's knighting and the character's in-canon death in Dragons of Winter Night, Williams can make such parallels between Perceval and Sturm, especially as Williams is one of the originators of the Dragonlance setting - he wrote all of the poetry and songs for the original trilogies and modules by Margaret Weis and Tracy Hickman, and was thus with them from the inception of the world. Margaret Weis herself, in fact, told me that she does not "see Sturm so much in Arthur as [she does] in Parsifal [Perceval]" in our early email correspondence about the creators' informing myths and legends - hence his quest for knighthood, his naïveté, and his attainment of a knighthood far later in his life than he deserved (Weis, 2019). She did say, however, that "Camelot is the largest shared world in history" (Weis, 2019), and as such is always a reference point for knights in fantasy literature - both to readers as well as to authors - perhaps most especially for Sturm and for Williams's presentation of the young knight-to-be in particular. While Weis gravitated toward Perceval more than Arthur, Tracy Hickman - who actually wrote Sturm's death - pulled from the Arthurian model, and Williams turned to Gawain for The Oath and the Measure.

After Williams glosses Sturm's upbringing - recapping what Thompson and Carter and Weis and Hickman had written before him - he delves into his own preferred view of Sturm: as a Gawain figure. Williams does this by appropriating the story of Gawain and the Green Knight and placing it into the world of Dragonlance. Williams, an Associate Professor of Comparative Humanities at the University of Louisville, knows his source, of that there can be no doubt: the appropriation of the Gawain-Poet is not only intentional, but also fits in with the character development and characteristics already associated with Sturm. Sturm's first Yule in Solamnia quickly becomes a test not only for himself against a version of the Green Knight, but also a test for the faltering Knights of Solamnia themselves - those same knights who no longer hold the Oath of honor in their hearts. As the Solamnics celebrate the Yule feast and pray to their hero, Huma Dragonbane, something odd occurs. A flute begins to play, "and with the music a rain of light, green and golden [...] Lord Wilderness appeared in the rafters above them, bristling with music and green sparks" (Williams, 2003: 6-7). This astonishing entrance, awash in green imagery, is only the beginning of the journey upon which Sturm will embark to prove his own honor and to defend the collective honor of the knighthood he holds so dear. This entrance, however, is not unique to "Lord Wilderness," the green man who will reveal himself as Vertumnus; Williams appropriates and adapts this entrance from a more famous green man, Bertilak the Green Knight. The Gawain-Poet has his green man enter Arthur's court in similar fashion: 
Anoper noyse ful newe nezed biliue,

Pat pe lude myzt haf leue liflode to cach;

For vnepe watz pe noyce not a whyle sesed,

And pe first cource in pe halle dor an aghlich mayster,

On pe most on pe molde on mesure hyghe;

Fro pe swyre to pe swange so sware and so pik,

And his lyndes and his lymes so longe and so grete,

Half-etayn in erde I hope pat he were,

$[\ldots]$

And alle his fetures folzande in forme, pat he hade,

Ful clene.

For wonder of his hwe men hade, set in his semblaunt sene;

He ferde as freke were fade,

And oueral enker grene.

[Another noise that was new suddenly drew near

So that their lord might at last have leave to take food;

For hardly had the music but a moment ceased,

And the first course in the hall been served as was custom,

When there came through the portals a fearful horseman,

The mightiest on middle-earth in measure of height;

From his gorge to his girdle so square and so thick

And his loins and his limbs so long and so large,

Half-troll on the earth I know that he was,

$[\ldots]$

And all his features followed in form, that he had,

In mode.

For men had wonder at his hue, set in his face and form that showed;

He passed as a fey-man fell,

And all over glowed green. $]^{2}$

11. 132-40, 145-50 (Malcolm and Waldorn, 2008)

While the manner of their entrances is not the same, many similarities can be noted, and that is what makes it appropriations rather than adaptation: a sudden noise interrupts the feast and heralds the arrival of the intruder, the intruder is covered in green, and he acts as a harbinger of some test or travail yet to come. The physical descriptions of Vertumnus and the Green Knight are truly the most similar. Sturm is amazed at Vertumnus, and Lord Wilderness is described:

The man's armor glistened with the waxy, depthless green of holly. Embossed roses, red and green, intertwined on his breastplate, and leaves and scarlet berries cascaded from his gauntlets and greaves, trailing behind him like a rumor of spring in the lifeless midwinter hall. About his face, more leaves flared

\footnotetext{
${ }^{2}$ My translation.
} 
and clustered like green flame, like a glory of grassy light, at the center of which his wide black eyes darted and glittered and laughed. He was a huge green bird or a dryad's consort [...] "I am Vertumnus," said the intruder, in a voice mild and low. "I am the seasons turning, and I am the home of the past years."

(Williams, 2003: 7-8)

The green man, in green armor and leafy countenance, is seemingly the embodiment of spring in a lifeless, northern winter. He heralds more than just a challenge to the knights, as will be discussed later, but also the coming of spring and magical changes to both the land and to a certain young knight-to-be. The Green Knight in Arthur's court is himself "al grayped in grene pis gome and his wedes" [All dressed in green this man and his clothes], and "Wel gay watz pis gome gered in grene" [Very gay was this man geared in green] (11. 151, 179) (Malcolm and Waldorn, 2008). Perhaps the most startling thing about the Green Knight are his eyes, which "loked as layt so lyzt" ["[his eyes] looked as bright as lightning"] (11. 199) (Malcolm and Waldorn, 2008), a startling similarity to Vertumnus. Both men are seemingly fey beings, imbued with magic and with green hues: the Green Knight and Vertumnus are more than they seem, but are wrapped in the mysterious air of the woods and the green spring. Green is, of course, the color of the natural world and wild magic, which serves as a stark contrast to the grey hues of the armored knights in either court. Their outlandish appearances and their startling entries into their respective courts are challenges in and of themselves to the assembled knights, who thought only to celebrate Yule, not to receive a strange visitor.

Helen Cooper remarks on this kind of disturbance, saying that in $\mathrm{Sir} \mathrm{Ga}$ wain and the Green Knight, there is "a clash between the ordinary human and knightly world of Arthur's court, and something that presents itself as profoundly other" (Cooper, 1997: 286). The same can be said of the disturbance in The Oath and the Measure, as we must remember that, though this is a fantasy setting, Thompson and Carter's story "The Exiles" establishes that magic is not something that knights should know about, nor is it something with which they should involve themselves, as Sturm paraphrases the Solamnic Measure when he says, "[magic is] not a fitting subject for knights" (Thompson and Carter, 1987: 207). While in Arthur's court, the Gawain-Poet has presented a world as without magic as possible for Arthur - at least in the beginning of the poem - as there is no Merlin, and no mention of anything as exotic as what the Green Knight represents. As Cooper suggests, the arrival of the Green Knight is made all the more shocking for this reason as "this has not seemed to be a world where such things could happen" (Cooper, 1997: 287). It is strange to think that a fantasy world like Dragonlance could have men like the Solamnics, so dead set against magic that they are unnerved by it, but this is another case where the appropriated 
content is making itself known: the shock of Vertumnus is equal to the shock of the Green Knight, and their tests for Sturm and Gawain, respectively, are made all the more fantastic as a result. Both tests, again, are meant to expose shortcomings within the knights themselves, and both Gawain and Sturm fail. While many of these elements might arguably be considered adaptation, enough is changed, revised, and placed within the setting of the fantasy world to become something else as well, showing how a Middle English narrative can live on in a fantasy setting by the act of appropriation, even if many of the readers do not know the story of Sir Gawain and the Green Knight. Because the template of the Arthurian narrative is used in the modern novel, it continues on as something else, something new, while remaining tied to the Middle English Arthurian tradition.

Akin to the Green Knight upon which he is based, Vertumnus comes to expose the lack of courage, honor, and devotion to the knightly ideal they allegedly follow. Vertumnus says to the knights that "I wish to make a point near and dear to my heart [...] You Solamnics gather like owls in these halls in the dead of the year [...] hooting of dark times and times past and how far the world has tumbled from ages of dream and might" (Williams, 2003: 8). The green man mocks the knighthood for only looking towards themselves and talking of their past glories and honors while the world around them moves on and is in trouble, playing a role that Bedwell does not find in Arthuriana: the green man desires to correct the knights who have lost their way and do not remember their Oath, just as Arthur's knights often fail in their own Pentecostal Oath. In this manner, Vertumnus serves as a revision to the Green Knight, as his intention was to find "zif it soth were / Pat rennes of pe grete renoun of pe Rounde Table" [if the great renown the Round Table [knights] earned was true] as he was charged by Morgan le Fay to do, and to perhaps cause the queen's death by this stir of magic and mystery (11. 2457-58) (Malcolm and Waldorn, 2008). Rather than a test to see if anyone would be willing to take up his challenge simply to verify if the Round Table was as honorable as they say - and they very nearly were not - Vertumnus wants to bring the knights low, to expose the hypocrisy they have allowed to flourish with the new generations of knights. Here, Williams provides an interesting insertion to the Arthurian tradition: a revision to a perceived lack, as Bedwell might perhaps view it. Sturm has a chance at redeeming the knighthood in a way that Gawain could not, as Bertilak's test is revealed as simply a way for Morgan le Fay to shock Arthur's queen and the court. Vertumnus, however, wants to prove to Sturm that the knighthood has fallen, and can be better than they are currently - the test is a way of correcting the course of events, and Sturm, though he does not yet know it, will go on to unite the knighthood through his courageous death, thereby eventually succeeding in Vertumnus's ultimate test of the knighthood's virtues. The appropriation, then, is the matter of revision to the extent of the test, and the overarching scope of it: while Gawain wears a garter forever more, Sturm pays a real price but is triumphant in the end. 
Unlike Arthur's court, a few Solamnic knights do attempt to take up Vertumnus's challenge, but they are all older knights of Angriff's time, not the young knights of the new generation. The only young man who takes up the challenge is not yet a knight: it is Sturm Brightblade. In the name of his father and the ideal Order of knighthood that only he seems to follow, he challenges Vertumnus. The green man reveals that he knows of Sturm's father, and "With a swift turn of the wrist, as bright and elusive as summer lightning, Vertumnus's sword flashed by Sturm's uncertain guard and plunged deep into his left shoulder" (Williams, 2003: 14). The wound heals before his very eyes, though the pain does not subside; in turn, "[Sturm's] blade drove cleanly into [Vertumnus's] chest" (Williams, 2003: 15). This trade of blows is similar but not exactly the same as the "game" the Green Knight proposes in Arthur's court. However, Vertumnus's wound heals as miraculously as Sturm's own, and Vertumnus says:

You have entered my game. Which, alas, you must now play to its end, as your shoulder will tell you daily and nightly [...] Meet me on the first day of spring [...] In my stronghold amid the Southern Darkwoods. Come there alone, and we shall settle this - sword to sword, knight to knight, man to man. You have defended your father's honor, and now I challenge yours. For now I owe you a stroke, as you owe me a life [...] If you fail to meet me at the appointed place, on the appointed night, your honor is forever forfeit.

(Williams, 2003: 17)

Indeed, not only are Sturm's and the knighthood's honor at stake, but Sturm will die from his magic wound should he fail. This game is much the same as the one in which Gawain finds himself: though Gawain's life is never in real danger, he does not know this and believes he is to die at the hands of the Green Knight, as Sturm believes himself doomed by Vertumnus. Like Gawain, Sturm is tested along the way, and both young men never know what is and what is not a part of that test - nor whether they can live up to it or not. Gawain must deal with Bertilak's wife while Sturm has many encounters with bandits, traps set by a traitor knight, and obstacles that Vertumnus himself throws in Sturm's way. Both men are tested as a part of the game, and though both men keep their oaths, they fail in other ways. Though the alterations to the Gawain narrative are many, the reworkings make the same general framework fit both in the corpus of Arthurian literature and in the fantasy setting of Dragonlance - aligning with Sanders's ideas on mythic appropriation. The changes to the overall structure, however, are what makes The Oath and the Measure an entirely separate product, created to fit into a fantasy setting that exists with its own separate rules, as indeed the Dragonlance setting must follow the Dungeons \& Dragons basic rules and formats. Due to these nuances and structural guidelines, while the narrative can be generally followed, there are too many changes in the order of events, character actions and names, and even the basic plot structure to call this 
an adaptation. Indeed, only the introduction to the test itself and to Sturm's journey can be easily recognized as a strong link to the Middle English Arthurian narrative poem it uses as a source.

Gawain's failure is well-documented and well-known: he keeps the girdle that Bertilak's wife assures him will save his life rather than give it to his host, as their deal required. Sturm's failure is more subtle even than is Gawain's. Sturm's failure is perhaps even less of one, as he believes that he fails to keep his appointment with Vertumnus, but, in truth, Vertumnus was with Sturm at this time. Sturm is forced to fight a treant, a literal green knight made of trees and other greenery, and is wounded (Williams, 2003: 202-07). Sturm's wound is healed while Vertumnus himself watches over Sturm and gives him three dreams of his father, Angriff, whom Vertumnus served under as a knight (Williams, 2003: 233). These three dreams are the equivalent of the three "strokes" given to Gawain by the Green Knight in the medieval poem. Gawain is not killed, and the Green Knight reveals the truth to him, just as Vertumnus reveals the truth about Sturm's father and Boniface's betrayal to the young man. While Sturm is technically correct when he wakes and muses that "I have missed my appointment with Lord Wilderness, or squandered it dreaming" (Williams, 2003: 243), it is Vertumnus's "fault" that Sturm was not awake to meet the green man, just as the Green Knight knew and did not blame Gawain for keeping the girdle that would save his life. Both Gawain and Sturm fail, but only fail a little; their failures are miniscule when compared to the knighthoods' failures at large, as no one else even attempted to live up to their respective Oaths and take on the "game" proposed by the courtly interlopers.

In case the Gawain appropriation was not clear enough, Williams makes his Middle English connections more explicit when he introduces Druidess Ragnell, a woman who is at certain times ugly and old and at other moments beautiful and young (Williams, 2003: 226). "The Marriage of Gawain and Dame Ragnelle," an anonymous fifteenth-century poem which shares a source with Chaucer's "Wife of Bath's Tale," tells of Gawain's marriage to a "loathly lady," Ragnelle, who is able to change her appearance in a similar fashion as the Druidess Ragnell is in Williams's novel. The tempting of Sturm differs here, as Ragnell is not meant as a choice of fates in love. Rather, Vertumnus, via Ragnell, gives Sturm a choice of fates for his own life: to remain a man and never learn the truth of his father, thereby gaining the power to expose the traitor among the Knights of Solamnia or to embrace his "wound," which is in truth a way of welcoming Sturm as Vertumnus's successor as Lord Wilderness, thereby gaining all of Vertumnus's powers and knowledge (Williams, 2003: 236-39). Sturm bids her to "Remove this thorn from my shoulder," and when she refuses, his response is "To the last of this and anything [...] I can choose" (Williams, 2003: 239). Sturm's choice means that his fate is sealed: his future is set, and he will not attain knighthood until long after this adventure, much like Perceval. Unbeknownst to Sturm, but known 
to Vertumnus, the knight-to-be also places himself on the path to his untimely death so that he may serve as an example for the Solamnics, who must learn to embrace change and turn away from politics and back to the Oath of honor.

Though Sturm is not a knight at the end of his adventure, the traitor is exposed by Vertumnus, clearing the honor of the knights. This change from the Gawain narrative is vital to Sturm's character, and as such is important to note. Sturm, exiled once more, is destined for other adventures, and, of course, his eventual Arthurian death. Sturm's "bending" of the Measure established in "The Exiles" is not at an end; in fact, he strives to live by the meaning of The Oath and the Measure rather than its words and denotations. I argue that Williams in particular appropriates Arthurian content to not only keep the legend alive, as Sanders would argue, and provide knowing readers "aha!" moments, as Raymond $\mathrm{H}$. Thompson suggests is a driving force, but also to ground his own narrative of Sturm. Because of Williams, Arthurian content is now an intrinsic part of the Dragonlance saga, and the appropriated content lives on for as long as the novels are read and reread by fans, even if those fans are mostly unaware of the Arthurian sources. Perhaps those fans will seek out the sources, perhaps not. Even if they do not, the act of transference from Middle English verse to Dragonlance novel still occurred, and the Arthurian content remains a part of the narrative structure. However, I argue that when one writes of a knight - any knight - a reader automatically recalls what he or she knows about knights of any fashion - questing in particular, and considers what in fantasy and in Arthuriana is connected to such characters. It is because Arthuriana is such a pervasive part of our culture that anyone reading of questing knights like Sturm calls to mind legends of Arthur and his Round Table, which affirms Sanders's idea of keeping the myths alive and infinitely reusable.

Williams not only preempts such an association, but he encourages it by appropriating and reworking the Gawain narrative and giving a revised version to Sturm to provide a suitably "knightly" backstory for a character who dies halfway through the original trilogy, leaving his origins both mysterious and open. Williams, as a professor himself, presents his own familiarity with Arthuriana through his work in the Dragonlance setting, allowing both for readers unfamiliar with the Gawain-Poet to, as Raymond H. Thompson argues, go back and find medieval Arthurian works to read (Thompson, 1985). It is more likely, however, that Gawain's narrative, his journey from the only knight to take up an impossible quest to a knight who, though he has failed, has seen the kind of knight he is and strives to be better than he has proven himself to be. This is also the driving force behind Sturm's character arc: a man who is a knight in all but name strives to be worthy of the legacy his father left him, to mend the shattered and overlystrict Knights of Solamnia, who have proved wayward in their duties. Gawain, at the conclusion of Sir Gawain and the Green Knight serves as a corrective force for himself, while Sturm serves as a corrective force both for himself and for 
the tarnished Solamnic Order he holds so dear. Just as Gawain uses his failure to remind him to be better, Sturm uses his past as a way to seek to live up to The Oath and the Measure, to live by "my honor is my life" and help others to see that only through failure and the striving to do better can anyone achieve their goal - their grail. Such is why Williams used the Gawain-Poet, and Sturm is now a part of a long line of famous knights who, while far from perfect, are worthy of their legacies, both in literature and to readers.

Sturm's journey does not end with Gawain's narrative, however. Sturm has, in turn, been raised as Perceval, quested as Gawain, and learned as both men. However, Sturm has two other Arthurian roles to play: he seeks the truth of the gods as does Galahad, and dies as does Arthur - as a rallying point, as a legendary figure. Sturm's search for his father and his quest to become a knight is still not completed years after Williams's The Oath and the Measure and Paul B. Thompson and Tonya C. Cook's Darkness and Light. The original Dragonlance novels, Dragons of Autumn Twilight, Dragons of Winter Night, and Dragons of Spring Dawning were written long before Williams's novel of Sturm, but they take place many years after Sturm's adventure with the green man. One of the first things the reader learns about Sturm in Dragons of Autumn Twilight is that he has still not found his father: "I heard rumors. Some say my father is dead. Some say he is alive [...] But no one knows where he is" (Weis and Hickman, 2002: 42). Angriff's fate has never been confirmed, not even by Weis and Hickman. Williams, though he writes of the three dreams given to Sturm that show him the siege of Castle Brightblade, never confirms that Angriff is alive or dead. In this sense, Williams, Thompson and Cook, and Weis and Hickman engage with the mystery of Arthur. It is the same as in Malory, who refuses to say one way or another if Arthur is dead or still alive in Avalon - merely saying that the Britons believe he is alive still and will return - so Angriff's fate is unknown. Angriff, like Arthur, has cast aside his wonderful sword and left his name and his legacy in the hands of his heir. Unlike Arthur, however, Angriff has chosen an heir who is as strong - indeed, much stronger - than he himself, and it is Sturm who does what Angriff could not: unite the knights of Solamnia once again.

Sturm's quest for his father is inexorably tied with his quest for the true gods and their ability to unite the Knights under their reign. In the world of Dragonlance, the gods left the world after the Cataclysm, when the Kingpriest of Istar demanded to become a god himself as he believed he knew better than the gods themselves. Angriff Brightblade still believed in the gods centuries after their alleged abandonment of the races of the world, and he passed that belief down to the young Sturm, who so fully conflated his father with the gods that, to him, finding one inevitably meant finding the other. As a result, Sturm chose to help Goldmoon, the first priestess of the true gods in hundreds of years: originally, he was merely helping a woman who needed aid, fulfilling his knightly Oath, but when she brought word of the gods, Sturm finally found the faith he had 
been searching for, and took time away from his quest for knighthood to help spread word of the gods of light (Weis and Hickman, 2002: 40-41). While there is no physical Grail associated with this quest, the search for confirmation of faith makes Sturm a Grail Knight in much the same way as Galahad: though far from perfect, Sturm allows his faith, both in the gods and in the knighthood of his father, to guide his actions. And yet, during all of this, he is still not yet a knight. Like Perceval, he acts as one, follows their code of chivalry to the best of his abilities, but he is not made a knight until his deeds are nearly done. This amalgamation of Arthurian characters in one knight, while complicated both to trace and to explicate, is a perfect example of how Sanders's ideas of the appropriation of mythic elements works in literature. It must be remembered that, unlike Thompson, who argues that fidelity is key, Sanders states that "a myth is never transported wholesale into its new context; it undergoes its own metamorphoses in the process. Myth is continuously evoked, altered and reworked, across cultures and across generations" (Sanders, 2016: 81). The evolution of Arthuriana is not only what keeps it alive, but what causes it to remain a useful context and framework for modern and contemporary authors. Without the ability to appropriate, to use myths with inherent changes and reworkings, not only would Arthur's story die out, but knights like Sturm would have no contextual basis for their actions; he would be another warrior amongst warriors rather than a complex character with a specific destiny. Arthuriana's usefulness to modern writers, then, is its inherent knowability, its recognition to audiences. Authors, of course, use this to situate characters like Sturm in a lauded list of similar chivalric literary heroes. Sturm can thus enter into a literary conversation about knights with Arthurian contexts that can be traced to literary texts through the methodology presented herein, and a further, critical discussion of Dragonlance and Arthuriana can be found in the middle.

When Sturm is rejoined with his friends in Solace before their harrowing adventures which, ultimately, lead to his death, Caramon asks Sturm if he is a Knight of Solamnia. Sturm visibly reacts to this question, but does not answer: "Sturm's smile vanished. Ignoring the question, he caressed the hilt of his sword lovingly" (Weis and Hickman, 2002: 42). It is important to note that Sturm does not lie. He never confirms that he is a knight, because he is not one; however, he also does not correct the assumptions of others, which might be seen as a lie of omission, if it can truly be called that. Perhaps this is his only real failure, and, like Gawain, he fails only a little. However, most surprisingly, it is Raistlin the wizard, the most unlikely champion for a knight, who comes to Sturm's defense in Dragons of Summer Flame, saying to Sturm's son:

He lied to us. Sturm Brightblade was no more a knight than I was. He was made a knight only shortly before his death. All that time, he wore the armor, carried the sword [...] and it was all a lie [...] And do you know what? I liked 
him better after I discovered that [...] Your father lied to every person except one - himself. In his heart, Sturm was a knight. He had better claim to that false title than many who held it for truth. Sturm Brightblade obeyed laws that no one enforced. He lived by a noble code in which no one else believed. He swore an oath that no one heard. Only himself [...] and his god. No one would have held him to that oath, to the Measure. He did that himself. He knew himself.

(Weis and Hickman, 2001: 491)

Weis and Hickman have done more here than they perhaps realize - or they have done exactly what they have meant to do. Laura K. Bedwell's issue with Arthur's Pentecostal Oath is that "Arthur is ultimately responsible for the enforcement of the Oath's penalties" should a Round Table Knight break it (Bedwell, 2011: 6), but the problem remains that "Arthur fails to carry out the Oath's provisions in full" and fails to hold the knights who break any of the strictures responsible for their actions (Bedwell, 2011: 7). Sturm has done what none of Arthur's knights - save the three Grail Knights, Bors, Perceval, and Galahad can do, according to Bedwell: he holds himself responsible for his actions, for the Oath and Measure that he was not required to follow by anyone other than himself. Sturm becomes, if not the perfect Arthurian knight, at least a knight who can and does act responsibly when none of the true knights around him are held accountable. Much like the Pentecostal Oath of Arthur, the Solamnic Oath and Measure are not truly enforced when they should be, only when convenient. Sturm does not rely on anyone else - especially not a king - to hold him to his Oath. Sturm lived "my honor is my life," even to the point where Raistlin, a man Sturm barely tolerated in life, remarks on his resolve and knightly bearing. Like Perceval, Sturm is not a knight until the end - but he lived as one for as long as it mattered. Weis and Hickman have created a revised Arthurian knight, one who resonates with a flawed but striving humanity - and yet emerges as a nearmythic hero. What might be seen as a change to a "classic" character motif, the chivalrous knight, in both fantasy fiction and Arthurian literature can, of course, be shown to be not startling revelation at all, but an appropriated character trait from Middle English Arthuriana. Indeed, Margaret Weis's own admission that Sturm is a Perceval character could lead the reader to find that Perceval was not made a knight until his adventures were nearly over in the Middle English tradition, and so it should not shock them that Sturm is no different. What truly matters is that Sturm does not fail to act like a knight, and lives his own version of knighthood and honor, fully engaging with the rules of his own order and with the established orders of chivalry in Arthurian tradition.

In one of his more popular and oft-quoted annotations to Dragons of Winter Night, the second book in the Dragonlance Chronicles, Tracy Hickman writes of what he calls "children's tales," by saying that, "[they] have a staying power that far outlasts any other form" (Weis and Hickman, 2002: 493). This proves 
both their usefulness for situating other narratives as well as their ability to be easily recognized by large audiences. Hickman, in this annotation, references what Tolkien might call "fairy stories," but perhaps has a better definition in folktales, in myths and legends. Hickman states many times in similar annotations and convention interviews that he is influenced by every major mythos and legendarium and strives to adapt such stories into his work. Weis as well, in her brief correspondence with me, states that "Tracy and I were inspired by many myths and legends when writing the [Dragonlance] novels," and she includes the Matter of Britain in those myths and legends (Weis, 2019). One of the most famous parts of the Arthurian legend is, of course, Lancelot and Guinevere's affair, which also has a presence in the Dragonlance novels, but is revised in such a way as to become something more fitting with Sturm's knightly ideal.

In Dragons of Winter Night, Sturm comes to the defense of a mysterious elven woman in court. After their escape from the corrupt law-enforcement of the city of Tarsis, Sturm continues to assist the woman, who is revealed to be Princess Alhana Starbreeze, heir of the king of the Silvanesti elves (Weis and Hickman, 2002: 536). Because she will one day rule the elves as their queen, she is destined to marry an elf prince, a nobleman of her own race. Though she eventually does marry, uniting the two main races of elves - the Silvanesti and Qualinesti - Alhana did not marry for love. If she had, she would have married Sturm. Like Lancelot and Guinevere, Sturm and Alhana are thrown together by fate, and their attraction cannot be denied - though they can never give in to it. As Tarsis burns in dragonfire, the two are thrust together:

Alhana, chaste maiden of a stern and rigid people, had long known when, where, and whom she would marry. He was an elflord, and it was a mark of their understanding that, in all the years since this had been arranged they had never touched [...] Alhana looked up into Sturm's grieved face and saw etched there pride, nobility, strict inflexible discipline, constant striving for perfection - perfection unattainable. And thus the deep sorrow in his eyes. Alhana felt herself drawn to this man, this human. Yielding to his strength, comforted by his presence, she felt a sweet, searing warmth steal over her, and she suddenly realized she was in more danger from this fire than from the fire of a thousand dragons.

(Weis and Hickman, 2002: 553-554)

Unlike Guinevere, however, Alhana does not give in to her desire. She knows that her people are more important than her own happiness, and Sturm's own destiny does not allow for such love. It is the fact that neither so much as speak of their desire to each other that makes this revised Lancelot-Guinevere affair much sadder and more pivotal to the world of Dragonlance: if they had given in, they would have doomed their world, just as Lancelot and Guinevere added to the downfall of Camelot. Sturm would not have united the Knights of Solamnia 
and Alhana would not have united the elves. This relationship shows a courtly love situation that never reaches fruition, one that has many of the hallmarks of such twelfth-century relationships, but one that is never consummated. The love between an elf and a human, in this instance, will remain ever chaste, and perhaps purer because of it, providing a touchstone for both characters in the future.

However, Alhana does not forget about the human she loves. In Dragons of Summer Flame, Tanis Half-Elven, the only person who knew of Alhana and Sturm's attraction, "wondered what Alhana, elf-queen of the Silvanesti, thought of the man she had married for the sake of politics. Had she come to love him as well?" (Weis and Hickman, 2001: 128). Alhana and her husband barely interact, and their child serves as the elven kingdoms' heir; Tanis knows that her love is buried with Sturm Brightblade. The appropriation of the knightly love affair with a queen he cannot have is revised to become even more tragic than Lancelot and Guinevere's: though their love caused the final dissolution of Arthur's Round Table, they at least had each other, however briefly. Sturm and Alhana, in contrast, did not even have that. They merely have the memory of their loveat-first-sight romance that could never be, and Alhana, at least, must live with that knowledge. In this sense, the Arthurian appropriation is one of sorrow and loss. However, one of the most famous love affairs in literature helps to frame a similar narrative in the world of Dragonlance - a "children's story" becomes context for a new relationship. Sturm's true legacy, like Arthur's, is his death and status as a unifier. The Knights of Solamnia are divided: the younger knights, led by Gunthar Uth Wistan - Angriff Brightblade's old friend - are in favor of following The Oath and the Measure as Sturm does, holding oneself accountable and believing in the spirit of the words; the other faction, led by Sturm's rival Derek Crownguard - nephew of Boniface, the traitor of Williams's The Oath and the Measure - is in favor of the current practice of strict adherence to the politics of court and the application of The Oath and the Measure among the Solamnic nobility. According to Crownguard and his followers, Sturm has lived outside of Solamnia "for too long" (Weis and Hickman, 2002: 765) and does not understand that the knighthood is a political order. Sturm's childhood away from court, like Perceval and Arthur, affects his way of seeing things: he is idealistic, and that ideal can only work if people hold themselves to the Oath, "my honor is my life," and not to court politics and bootlicking. At Sturm's trial for failing to follow Derek's orders, events recounted in Dragons of the Highlord Skies, and for purporting himself to be a knight when he is not one, Sturm is unable to contend with the political situation (Weis and Hickman, 2002: 758-72). Like Perceval, he has no conception of being a knight in this scenario. In Sir Perceval of Galles, Arthur is astonished that Perceval's mother has failed him so horribly, as "The childe hadde wonnede in the woode; / He knewe nother evyll ne gude," (11. 593-94) (Braswell, 1995). Perceval's mother, Arthur's own sister, did not teach him to be a knight. Likewise, Gunthar is saddened that Lady Ilys taught 
Sturm how to be an ideal knight and not how to function in courtly politics. Without this training, Sturm may as well be the rustic that Derek believes him to be - at least until Sturm is made a knight.

Based on the testimony of his friends about his heroic deeds, Sturm, like Perceval is made a knight shortly before the end of his own story. Like Arthur, he helps Perceval because of his father's deeds (11. 15773-84) (Braswell, 1995). So too does Gunthar assist Sturm because of Angriff (Weis and Hickman, 2002: 769-70), propping the younger man up on Gunthar's own word of honor and admitting him into the knighthood. Gunthar is also much like Arthur, as he is the one to use Sturm's memory as a rallying point for the restructuring of the Knights of Solamnia, as is revealed in Dragons of Summer Flame. It is said there that, since Sturm's death and under Gunthar's unified leadership, the knights "were now seen as protectors of the weak, defenders of the innocent. Wiser lords had risen in the ranks; the laws set down by Vinas Solamnus thousands of years ago - laws had been religiously, strictly, and some said, obtusely followed in the modern era - were being revised and modified, brought up to date" (Weis and Hickman, 2001: 173). It was not Gunthar alone that could have accomplished this, however. The knights needed a hero, a unifying mythic figure, to use as a rallying cry, and Sturm knew that such was his destiny. Just as Arthur was used as the focal point for chivalric tales and knightly quests in the twelfth century and beyond, so too was the story of Sturm used by the knights opposing the armies of darkness. The mythic narrative of Arthur is used by Weis and Hickman for their own purposes, to create a figure for the knights to look up to as a paragon. Sturm realizes that the Measure has failed the knights, but the Oath of honor remains (Weis and Hickman, 2002: 875), and his adherence to "my honor is my life" serves as the culmination of his character arc. It is only because he lived away from court that he could see the truth of the knights; he realizes that his time with Tanis and the rest of his friends from Solace has given him the perspective he needs, much like T. H. White's Arthur, whose lessons from the animals allow him to see the world like no one else, to try and fight for a better world.

Sturm's experience with other races, the poor, and his travels in distant lands force him to see that the individual is ultimately responsible for trying to fix the world, not moldy old laws. This is the knighthood Sturm's death brings into being, the same kind of unity that Tennyson sees Arthur bringing to his people in Idylls of the King. Sturm sacrifices himself on the walls of the High Clerist's Tower to give the knights time to regroup and for Laurana to figure out how to defeat the dragons (Weis and Hickman, 2002: 880-81). Sturm muses that "The Forestmaster said to us, in Darken Wood, that we should not mourn those who have fulfilled their destiny. Mine is fulfilled" (Weis and Hickman, 2002: 881). Sturm means two things: his destiny of becoming a knight has been fulfilled with the help of Lord Gunthar, but Sturm also realizes that someone must serve as a catalyst for change in the Solamnics. Tracy Hickman writes in an annota- 
tion that "Sturm's death was no whim - it was his destiny in the story and his greatest act of sacrifice. Sturm became the catalyst for the knights to finally be forged as one" (Weis and Hickman, 2002: 883). Like Arthur, Sturm was destined to die. Like Galahad, he could only die after achieving his quest - for knighthood and for the true gods so that they could help the knights. Sturm is able to look back on the words of the Forestmaster from Dragons of Autumn Twilight and understand that she was referring to him and the fulfillment of the destiny the gods laid out for him. Sturm is killed by the Blue Dragon Highlord, his old friend - and mother of his son - Kitiara, and while "Sturm's sun shattered" (Weis and Hickman, 2002: 885), his sword, the Brightblade, remains whole, proving that he did not fail in his task. As the legend goes, he may have died, but he did not break. The Brightblade endures.

Magic swords are a staple in fantasy novels, particularly those set in the worlds of Dungeons \& Dragons. Such swords are, of course, an element of fantasy fiction made famous by Tolkien, from whom Dungeons \& Dragons - and Dragonlance with it - sprung. We must remember, however, that Tolkien himself was influenced by medieval romances and appropriated their elements into his own work, most especially magic swords such as Excalibur and the sword of Galahad. These kinds of magic or holy blades are often connected to a single wielder or to a father and son as an heirloom and a sign of rightful inheritance. While Tolkien and the authors of Dungeons \& Dragons had other such swords to draw on as well - particularly Gram, the sword of Sigmund and his son Sigurd - father and son are equally united by Uther's sword, which Arthur draws from the stone as a sign of his right to rule and as a sign of his true parentage.

In the novels of the Dragonlance saga, the sword of the Brightblade family, aptly called "The Brightblade," is a part of Sturm's inheritance from his father, who is lost and presumed deceased after the peasant uprising in their native Solamnia - later, the blade also serves as Sturm's inheritance to his own son, Steel. In the novel and the setting supplement Lost Leaves from the Inn of the Last Home by Margaret Weis, the Brightblade is given a suitable history and explanation of its powers. Weis writes that "the Brightblade is approximately 2,000 years old. Romgar Firesteel, a dwarven weaponsmith, crafted it for Berthel Brightblade as a reward for saving the dwarf's life" (Weis, 2007: 37). While a dwarven smith is no Lady of the Lake, the Brightblade, like Excalibur, has otherworldly, non-human origins, and serves as a symbol of heritage: Excalibur proves Arthur's might and right to rule while the Brightblade serves as Sturm's and later his son's - right to the Brightblade name and the right to the honorable title of knight and hero.

Each blade is more than a mere symbol, however, Malory gives Excalibur and its scabbard special abilities: as the sword never fails Arthur and the scabbard - while Arthur has it - means he cannot be wounded (Malory, 2017: 44). The Brightblade has an edge that is "extremely keen" and can cut "through any- 
thing lighter than plate armor as effortlessly as a knife cuts through warm butter [...] the blade has been enhanced in a way that no ordinary weaponsmith could" (Weis, 2007: 37). While magic is not specifically mentioned - as knights would have naught to do with it - it is implied that it has been "enhanced" somehow to perform beyond the means of normal swords, and very few knightly blades, even in a fantasy setting like Dragonlance, are so powerful. Weis continues by saying, "Solamnic folklore says that the Brightblade cannot break as long as its wielder is pure of heart and follows the tenets of Vinus Solmanus [the founder of the Knights of Solamnia] - honor, justice, and compassion. However, if its wielder sways from the path of Good, the sword will shatter, cursing its wielder" (Weis, 2007: 38). Sturm obviously follows these tenants - embodies them, as does Perceval and Galahad - proving that he is, in fact, worthy of his father's legacy. Sturm makes mention of this "legend" of the sword in the first pages of Dragons of Autumn Twilight, saying, "According to the legend, this sword will break only if I do" (Weis and Hickman, 2002: 42), reinforcing both the sword's mythic status as well as Sturm's own worthiness to wield it. It can be understood that only a true Brightblade is worthy of using the sword from which the family takes its name, much like the sword of Galahad in Malory, as he is the only one who can properly wield it - as Balin of the Two Swords found. The sword alone is like many other magic or blessed swords in fantasy fiction, but its association with an Arthurian amalgam like Sturm makes the connection to magic swords in the Matter of Britain.

In The Oath and the Measure, Sturm is given a false copy of his father's sword by Lord Boniface Crownguard, the traitor who caused Angriff's assumed death and uncle to Sturm's own rival to reclaim the knighthood for honor over politics (Williams, 2003: 52-53). Sturm does not realize that this blade is designed to break, to fail him; this is paralleled in Malory, when Arthur is forced - unknowingly - to fight Accolon, who wields the true Excalibur, as Arthur was given a fake by his sister in hopes that he would die. Though both Sturm and Arthur eventually reclaim their true swords, both men realize that there are traitors in their midst, and while Arthur overcomes his sister's plot, Sturm fails to expose Boniface on his own and is sent back into exile, all hopes of his knighthood vanishing for the foreseeable future (Williams, 2003: 292). Sturm is not, in fact, gifted with the true Brightblade until the end of Thompson and Cook's novel Darkness and Light. Angriff's armor and sword are left in the decayed husk of Castle Brightblade. Sturm's inheritance is conveyed by three simple words, "For My Son" (Thompson and Cook, 2003: 367). The words give him not only the armor of a knighthood he does not yet have, but the sword that proves his place as his father's heir and heir to the honor of the Knights of Solamnia - honor that Sturm will restore, in time. The Brightblade itself is Sturm's final connection with his father, just as Arthur only knew Uther by his legacy and by the sword he pulled from the stone. 
The Arthurian appropriation, in the instance of the passing of the Brightblade line, signals a great change in the world of Dragonlance, just as Arthur's passing heralded an end to a heroic age of chivalry. As Arthur's Britain faded away, if indeed it ever existed, so too has the world of Dragonlance shifted to a world where heroes are made rather than born, where grand destinies no longer play a part in the world. In both cases, the myth has passed into the world of the real. The same can be said, perhaps of literary forms themselves: Arthurian tales took many forms over their long history of adoption and adaptation, and their appropriation into different genres and textual mediums has allowed for their continued survival. While the Dragonlance novels discussed here can be read without any real knowledge of Arthuriana - and, in fact, are widely read by such audiences - a larger understanding of Sturm's characteristics and narrative journey can be found by paired readings with Arthurian sources. This follows the line of thinking that Julie Sanders establishes, and the ideas that I have endeavored to illustrate throughout this work by drawing connections between the works of the Dragonlance saga and Arthurian literature. The simple fact is that there is almost no critical work on the Dragonlance novels - most of the arguments of this text are my own observations and connections as I have sought to prove the appropriated content through the parallels explored herein. While plenty of work remains to be done, particularly with Sturm's son, Steel, the enduring popularity of Arthur and the loyal fanbase of Dragonlance are entwined in a way that allows for the myth of Arthur to be carried forward in the legacy of Sturm Brightblade.

\section{Bibliography}

Andrew, Malcolm, and Ronald Waldron, eds., 2008: Sir Gawain and the Green Knight. In: The Poems of the Pearl Manuscript: Pearl, Cleanness, Patience, Sir Gawain and the Green Knight. Liverpool: Liverpool University Press, 207-300.

Bedwell, Laura K., 2011: “The Failure of Justice, The Failure of Arthur.” Arthuriana, no. 21.3, $3-22$.

Braswell, Mary Flowers, ed., 1995: Sir Perceval of Galles. In: Sir Perceval of Galles and Ywain and Gawain. Kalamazoo, Michigan: Medieval Institute Publications, 7-76.

Brewer, Elisabeth, 1997: "Sources I: The Sources of Sir Gawain and the Green Knight." In: A Companion to the Gawain Poet. Eds. Derek Brewer and Jonathan Gibson. Woodbridge, England: D. S. Brewer, 243-255.

Cooper, Helen, 1997: "The Supernatural." In: A Companion to the Gawain Poet. Eds. Derek Brewer and Jonathan Gibson. Woodbridge, England: D. S. Brewer, 277-291.

Eco, Umberto, 1986: "Dreaming of the Middle Ages." In: Travels in Hyperreality: Essays. Trans. William Weaver. San Diego: Harcourt, 61-73.

Hutcheon, Linda, with Siobhan O'Flynn, 2013: A Theory of Adaptation: Second Edition. New York, Routledge. 
Lowder, James, 2019: Comment on "Wherein I trace the appropriation of the Middle English Sir Gawain and the Green Knight and Sturm Brightblade as a Gawain-Arthur hybrid figure." Facebook, 14 Jan. Web. 13 Jan. 2019.

Malory, Sir Thomas, (1485) 2017: Le Morte Darthur. Ed. P. J. C. Field. Woodbridge, England: D. S. Brewer.

Robertson, Benjamin J., 2017: "From Fantasy to Franchise: Dragonlance and the Privatization of Genre." Extrapolation: A Journal of Science Fiction and Fantasy, no. 58.2-3, 129-52.

Sanders, Julie, 2016: Adaptation and Appropriation: Second Edition. New York, London: Routledge.

Thompson, Paul B., and Tonya R. Carter, (1987) 2005: "The Exiles." In: Love and War: Dragonlance Tales Volume III. Eds. Margaret Weis and Tracy Hickman. Renton: Wizards of the Coast, 158-207.

Thompson, Paul B., and Tonya C. Cook, (1989) 2003: Darkness and Light. Renton, Washington: Wizards of the Coast.

Thompson, Raymond H., 1985: The Return from Avalon: A Study of the Arthurian Legend in Modern Fiction. Westport, Connecticut: Greenwood Press.

Weis, Margaret, 2007: “The Brightblade.” In: Lost Leaves from the Inn of the Last Home. Renton, Washington: Margaret Weis Productions, 37-39.

Weis, Margaret, 2019: "Re: Dragonlance." Gmail. Received by Carl B. Sell, 4 Feb. 2019.

Weis, Margaret, and Tracy Hickman, (1984) 2002: Dragons of Autumn Twilight. In: The Annotated Chronicles. Renton, Washington: Wizards of the Coast, 9-475.

Weis, Margaret, and Tracy Hickman, 2007: Dragons of the Highlord Skies. Renton, Washington: Wizards of the Coast, 2007.

Weis, Margaret, and Tracy Hickman, (1985) 2002: Dragons of Spring Dawning. In: The Annotated Chronicles. Renton, Washington: Wizards of the Coast, 913-1312.

Weis, Margaret, and Tracy Hickman, (1995) 2001: Dragons of Summer Flame. Renton, Washington: Wizards of the Coast.

Weis, Margaret, and Tracy Hickman, (1985) 2002: Dragons of Winter Night. In: The Annotated Chronicles. Renton, Washington: Wizards of the Coast, 476-911.

Williams, Michael, (1992) 2003: The Oath and the Measure. Renton, Washington: Wizards of the Coast.

\section{Bio-bibliographical Note}

Dr. Carl B. Sell is the TRIO SSS Writing Specialist at Lock Haven University. Carl's research explores appropriations of Arthurian legend narratives, characters, and themes in popular culture as an extension of the medieval adaptive tradition. He serves as a member of the advisory boards for The Association for the Advancement of Scholarship and Teaching of the Medieval in Popular Culture and the Alliance for the Promotion of Research on the Matter of Britain, and he is the author of various film and literature reviews on medievalist and scholarly blogs, as well as journal articles on Arthurian topics and DC's Aquaman.

cbs24@lockhaven.edu 